This is an Accepted Manuscript of an article published by Taylor \& Francis in Journal on the Use of Force and International Law, available online: http://www.tandfonline.com/doi/full/10.1080/20531702.2017.1313525

\title{
The Relationship Between National, Unit and Personal Self-Defence in International Law: Bridging the Disconnect
}

\author{
Chris O’Meara*
}

\begin{abstract}
Academic and judicial consideration of the right of self-defence in international law has focused on the right as it applies to states (national self-defence). This approach represents only part of the picture however. Little attention has been paid to how the right of national self-defence relates to, and interacts with, the right of military personnel and their units to defend themselves. Yet, this relationship is crucial to determine when and how a state may defend itself. This paper highlights fundamental problems associated with the focus on national self-defence, which results in the fragmentation of international law. It offers some unified thinking regarding issues of attribution, the gravity and timing of attacks, the requirements of necessity and proportionality and armed attacks by non-state actors. The aim is to bridge the current disconnect.
\end{abstract}

Keywords: self-defence; unit self-defence; personal self-defence; jus ad bellum

\footnotetext{
*PhD Candidate and Teaching Fellow, UCL Faculty of Laws. Email: christopher.o'meara@ucl.ac.uk. The author is grateful for the comments of Dr Kimberley Trapp. Any errors remain his own.
} 


\section{Introduction}

The issue of self-defence is one of the most contested areas of the jus ad bellum and of public international law more generally. In particular, heated debates continue over the meaning of an 'armed attack', which acts as the trigger for the inherent right of self-defence for the purposes of Article 51 of the Charter of the United Nations (UN Charter). ${ }^{1}$ Academic commentary on the constituent elements of an armed attack occupies volumes of scholarly literature. The well-known arguments highlight issues associated with whether a threshold of violence is required before a right of self-defence arises, the position of non-state actors in the equation and temporal issues pertaining to anticipatory self-defence. Perhaps as a natural consequence of the drafting of the UN Charter, directed as it is at the 'Members' of the UN, the overwhelming majority of this academic purview has taken place at the state level. That is to say the right of self-defence as it applies to states (national self-defence). This approach represents only part, albeit an essential part, of the self-defence picture however. Much less academic attention has been paid to how the right of national self-defence relates to, and interacts with, the right of military personnel and their units to defend themselves. The commentary that does exist on this point is primarily (although not exclusively) provided by military and government lawyers in the United States. There is a notable absence of input from jus ad bellum scholars. The International Court of Justice (ICJ or the Court) has also provided little elucidation on this fundamental question when it has been called upon to consider issues of national self-defence. By focusing on the level of the state and armed attacks against 'the state', the jurisprudence has contributed to a fracturing of the jus ad bellum. The result is an appreciation of the law that is far removed from those who face armed attacks on the ground, in the air or at sea.

The disconnect between the right of states to defend themselves and the right of individuals and units to do so, provides an incomplete picture of the right of self-defence. The purpose of this paper is to highlight some of the problems associated with the focus to date on national self-defence and to demonstrate how the right of personal and unit self-defence should and do fit into the analysis. It seeks to offer some unified thinking regarding the jus ad bellum that properly accounts for the position of the military. The aim is to invite further debate and scholastic and judicial consideration in order to bridge the disconnect. The hope is that this approach will contribute to clarifying some of the controversies that have persisted since the right of self-defence was expressly recognized by the UN Charter in 1945. The first part of this paper will offer an overview of the right of self-defence at the state, unit and personal levels, including how the latter two are reflected in rules of engagement (ROE) issued by states. It will then proceed to the substantive issues where the disconnect is most apparent. These include whether the right of self-defence should be viewed in a unitary

\footnotetext{
${ }^{1}$ Art 51 UN Charter provides that: '[n]othing in the present Charter shall impair the inherent right of individual or collective self-defence if an armed attack occurs against a Member of the United Nations, until the Security Council has taken measures necessary to maintain international peace and security. Measures taken by Members in the exercise of this right of self-defence shall be immediately reported to the Security Council and shall not in any way affect the authority and responsibility of the Security Council under the present Charter to take at any time such action as it deems necessary in order to maintain or restore international peace and security.'
} 
manner or separately at the state and personal/unit level. How attribution operates within this context will also be reviewed, together with the gravity of violence required before a right of self-defence becomes available at these different levels. The difficulties posed by imminent armed attacks and the requirements of necessity and proportionality will then be examined, together with specific considerations relating to armed attacks by non-state actors (NSAs).

What becomes clear when one considers these issues, is that much of the academic commentary and jurisprudence to date is missing a piece of the puzzle. They tend not to account for how legal norms operate on the ground and are then transmitted to the national level so that the right of self-defence of military personnel and units are treated as constituent elements of the right of national self-defence. Any suggestion that there are two levels of selfdefence that operate as legally distinct and separate regimes fails to recognize that national, unit and personal self-defence (as the latter applies to military personnel of that state) are one and the same thing. To ensure therefore that there is no disconnect within international law, we must be clear that the jus ad bellum treats self-defence in a unitary manner. There is only national self-defence, although the legal rights of individual military personnel and units form part of it. It is then the customary requirements of necessity and proportionality that govern what the overall defensive response looks like. To avoid fragmentation within the jus ad bellum, and in international law more generally, we should therefore consider the range of consequences of saying that a state has no right of self-defence against minor uses of force, or attacks by NSAs, or armed attacks that are imminent. What is required is a holistic approach that looks at self-defence in a consolidated fashion and considers how the different levels of self-defence work together. The present disconnect needs to be bridged.

\section{National self-defence, unit self-defence and rules of engagement}

\section{i. $\quad$ National self-defence}

Article 2(4) UN Charter prohibits the 'threat or use of force against the territorial integrity or political independence of any state'. The only explicit exceptions to this prohibition are force authorised by the UN Security Council (UNSC) pursuant to Chapter VII UN Charter and the inherent right of self-defence recognized by Article $51 \mathrm{UN}$ Charter. ${ }^{2}$ For a use of force to constitute lawful national self-defence under Article 51, a state must be able to prove the existence of an armed attack. The difficulty for a state in discharging this burden of proof lies in a number of hurdles that need to be overcome in respect of the nature and gravity of the attack. These include a review of what level of force is required to amount to an armed attack, who or what carries one out and when an armed attack starts and finishes. Any use of force that fails to meet these armed attack standards will not give rise to a lawful right of selfdefence, although may allow other responses on the part of the injured state. Whilst the ICJ in Nicaragua confidently stated that there appeared to be 'general agreement on the nature of the

\footnotetext{
${ }^{2}$ To be lawful, the exercise of self-defence must comply with both Art 51 UN Charter and applicable customary international law. The latter includes the requirements of necessity and proportionality, which are discussed in section III.v below.
} 
acts which can be treated as constituting armed attacks', ${ }^{3}$ nearly thirty years later such conclusion seems, at best, woefully optimistic. The UN Charter contains no definition of the term and no other treaty or any UN body, including the ICJ, has ever offered a comprehensive interpretation. A close analysis of the elements of an armed attack reveals that deep divisions and fundamental conceptual and operational controversies remain. Today, seventy years after the conclusion of the UN Charter, the judiciary, states and academics alike still hotly contest them.

It is not the purpose of this paper to go over these well-known debates. Rather, the aim is to highlight the gaps in such debates that arise by virtue of the fact that little consideration has been given to how the right of individual servicemen ${ }^{4}$ and their units to respond to armed attacks operates in relation to the inherent right of national self-defence, as recognized in Article 51. National self-defence is generally understood as being exercised at the state level. As discussed further below, it is viewed as a strategic decision to defend 'the state', involving the highest levels of political or executive decision-making. An exercise of national selfdefence may therefore be characterised as the response by the state 'as a whole' to an armed attack against it, which includes its citizens, territory and property. It is convenient for present purposes to describe this view of national self-defence as one that operates at the "macro level'. With a few exceptions, as noted below, it is usually at this level that scholastic opinion (at least amongst the majority of jus ad bellum commentators) and judicial consideration takes place. However, as sections III.ii and III.iii make clear, whether a state is de facto defending itself and/or has a de jure right to do so might be determined by actions or events occurring much lower down the chain of command. Depending on the circumstances, national selfdefence might be exercisable and/or exercised as a result of individual serviceman or military units exercising their inherent right of self-defence at the operational level. This paper refers to such self-defence as occurring at the 'micro level'. Whilst these acts might be viewed as localised and/or not of a sufficient scale to engage the state 'as a whole', as will be made clear, such incidents may nevertheless be rightly characterised as an exercise of national selfdefence.

\section{ii. Unit self-defence}

Unit self-defence refers to the right of military commanders to use necessary and proportionate force to defend their unit (and other units from their state) in the face of an attack or imminent attack. ${ }^{5}$ It is a right that is fundamental to all international military legal

\footnotetext{
${ }^{3}$ Military and Paramilitary Activities in and against Nicaragua (Nicaragua $v$ US), (Merits) [1986] ICJ Rep 14 (Nicaragua) para 195.

${ }^{4}$ For ease of reference, this paper adopts the masculine form, which should be read as including both the feminine and the masculine form.

${ }^{5}$ International Institute of Humanitarian Law, Sanremo Handbook on Rules of Engagement (November 2009) available at <http://www.iihl.org/wp-content/uploads/2015/12/ROE-HANDBOOK-ENGLISH.pdf> (Sanremo Handbook) paras 8(b) and 10. The Sanremo Handbook was prepared under the auspices of the International Institute of Humanitarian Law. Drawing together highly qualified experts from around the world, it purports to reflect best practice of a diverse range of states to rules of engagement. It therefore provides a useful source of
} 
codes $^{6}$ and applies exclusively to military units, regardless of their nature. ${ }^{7}$ For some states, in addition to being a right, the defence of the military unit is also an obligation. ${ }^{8}$ As the next section will discuss in more detail, the right of unit self-defence is an inherent right of military personnel to use force. It therefore mirrors Article $51 \mathrm{UN}$ Charter, which recognizes national self-defence as the inherent right of states. Whether or not unit self-defence is derivative of this Charter right is controversial however. ${ }^{9}$ For some, unit self-defence is a right sui generis of customary international law, thereby governed by the customary requirements of necessity and proportionality that also apply to national self-defence (see section III.v below) ${ }^{10}$ Others have noted however that, as a consequence of the differences between national jurisdictions pertaining to the right of unit self-defence, the military will exercise this right in accordance with its national laws, meaning that authorized military responses under the right of unit selfdefence will vary from state to state. ${ }^{11}$ These outer boundaries of self-defence, whether unit or national, will be discussed in section III.v below. Despite the controversies regarding the precise legal basis for the right of unit self-defence however, its existence is generally accepted. $^{12}$

Much of the following analysis concerns the right of unit self-defence and how it relates to national self-defence. However, we should not forget the individual in this equation. It is generally accepted that that all individuals (civilian and military) possess the right of personal self-defence, but this right primarily exists in the realm of criminal law and varies depending on applicable domestic or international criminal law. All domestic criminal justice systems recognize personal self-defence as a ground for excluding criminal responsibility. ${ }^{13}$ It has never been questioned that people have the right to defend themselves. ${ }^{14}$ Customary international criminal law also recognizes a right for individuals to defend themselves or their

information and analysis relating to rules of engagement of states and their relationship with national, unit and personal self-defence.

${ }^{6}$ Dale Stephens, 'Rules of Engagement and the Concept of Unit Self Defense' (1998) 45 Naval Law Review 126, 126.

${ }^{7}$ JFR Boddens Hosang, 'Self-Defence in Military Operations: The Interaction between the Legal Bases for Military Self-Defence and Rules of Engagement' (2008) 47/1-2 Military Law and The Law of War Review 25, 51-64. A military unit can consist of an army platoon, a ship, an aircraft, or might encompass a national or international task force that is operating as a single unit. The size or composition of the unit is not relevant, the operation as a single unit is. Terry Gill and Dieter Fleck (eds) The Handbook of the International Law of Military Operations (Oxford University Press, $2^{\text {nd }}$ edn 2015) 481.

${ }^{8}$ See notes 29-31 and related commentary.

${ }^{9}$ See e.g. Gary Corn 'Should the Best Offense Ever Be a Good Defense? The Public Authority to Use Force in Military Operations: Recalibrating the Use of Force Rules in the Standing Rules of Engagement' (2016) 49 Vanderbilt Journal of Transnational Law 1, especially 17-20. For the purposes of this paper, and as will be made clear, whether or not it is derivative does not affect how the right of unit self-defence engages the right of national self-defence.

${ }^{10}$ Stephens (n 6) 131-8; Hosang (n 7) 57.

${ }^{11}$ Sanremo Handbook, para 8; Gill and Fleck (n 7) 233.

${ }^{12}$ Gill and Fleck (n 7) 481; 482-4.

${ }^{13}$ Roger O'Keefe, International Criminal Law (Oxford University Press 2015) 214. Many also recognize defence of others, and some recognize defence of certain property.

${ }^{14}$ Robert Cryer et al, An Introduction to International Criminal Law and Procedure (Cambridge University Press, $3^{\text {rd }}$ edn 2014) 408. 
property (or another person or their property) against unlawful uses of force. ${ }^{15}$ This principle serves as a ground for acquittal under the Rome Statute of the International Criminal Court (ICC Statute). ${ }^{16}$ For military personnel, who are the focus of this paper, a claim of selfdefence may be raised in response to accusations of individual criminal responsibility for breaches of international humanitarian law (IHL), most notably, war crimes. ${ }^{17}$ Personal selfdefence, as part of the criminal law, is however distinct from the inherent right of personal self-defence as it relates to individual members of a military unit. ${ }^{18}$ In the military context, whilst the right is inherent to the individual, it will always be more limited than in the civilian context. ${ }^{19}$ It 'should be reserved as a safety net, a measure of last resort in the event that the mission-specific authorizations to use force, as set forth in the [rules of engagement], and [unit self-defence] are somehow insufficient to save one's life.' ${ }^{20}$ Full analysis of the relationship and differences between personal and unit self-defence is beyond the scope of this paper. ${ }^{21}$ For present purposes, it is accepted that both individual military personnel and military units have an inherent right of self-defence in response to actual or imminent unlawful attacks, provided always that the exercise of such right is both necessary and proportionate. It is also accepted that, for the purposes of attribution, the analysis regarding such right for individual military personnel will be the same as for their unit. It is the latter

\footnotetext{
${ }^{15}$ Prosecutor v Kordić \& Čerkez (Judgment) ICTY-95-14/2-T (26 February 2001) 448-52.
}

${ }^{16}$ Rome Statute of the International Criminal Court (adopted 17 July 1998, entered into force 1 July 2002) 2187 UNTS 3, Art 31(1)(c). The preconditions to the availability of the defence under the ICC Statute are that any acts of self-defence, defence of others or defence of specified property be reasonable, be directed against an imminent and unlawful use of force, and be proportionate to the degree of danger to the accused or to the other person or persons or the property sought to be protected. These cumulative conditions reflect the requirements of the analogous defence recognized by the major national criminal justice systems. O'Keefe (n 13) 215.

${ }^{17}$ As O'Keefe (n 13) 215, notes, it is difficult to imagine how it could successfully be argued that other international crimes such as genocide or crimes against humanity could ever be a reasonable and proportionate response to an imminent and unlawful use of force. But the defence does have a role to play in the context of certain war crimes. War crimes refers to 'those violations of international humanitarian law (...) that give rise to the individual criminal responsibility of the perpetrator under international law, whether customary or conventional. In terms of war crimes under customary international law, the label encompasses both so-called 'violations of the laws and customs of war' and the customary analogues of certain violations of the 1949 Geneva Conventions and their Additional Protocols.' O'Keefe (n 13) 124-5.

${ }^{18}$ Gill and Fleck (n 7) 484, 490, 499-500. On one view, unit self-defence may be seen as a collection of individuals, thus it a form of 'collective personal self-defence', although this is controversial and seems undesirable given the possible variation of law applicable to personal self-defence. Gill and Fleck (n 7) 482. However, overlapping with the right of personal self-defence, unit self-defence has been described as allowing 'a commander, or an individual soldier, sailor or airman the automatic authority to defend his or her unit, or him or herself, in certain well defined circumstances' (emphasis added). Stephens (n 6) 126.

${ }^{19}$ That self-defence only applies in response to an 'unlawful' use of force means that, in the majority of cases in armed conflicts, the right will be largely irrelevant. This is because combatants have a right to participate in hostilities. There is no right of self-defence in respects of lawful acts of war. In such instances, conduct is governed by the rules of IHL. In armed conflict therefore, combatants and those taking direct participation in hostilities may be lawfully targeted.

${ }^{20}$ Gill and Fleck (n 7) 499.

${ }^{21}$ For further discussion of the relationship between personal and unit self-defence, see Hosang (n 7) 52; Charles P Trumbull IV, 'The Basis of Unit Self-Defense and Implications for the Use of Force' 23 Duke Journal of Comparative and International Law 121 (2012-2013) 145-7. 
therefore that is the focus of much of the following analysis. These points will be explored further in the following sections.

\section{iii. Rules of engagement}

ROE are widely used by states to direct when and how military force is to be applied in both peacetime and in situations of armed conflict. Military forces accept these instruments as the most common and effective framework in which to control the use of force. ${ }^{22}$ The UK Law of War Manual defines ROE as 'directions for operational commands that set out the circumstances and limitations under which armed force may be applied by United Kingdom forces to achieve military objectives for the furtherance of United Kingdom government policy'. ${ }^{23}$ In comparable terms, the US Law of War Manual provides that:

[r]ules of engagement (ROE) have been defined as "[d]irectives issued by competent military authority that delineate the circumstances and limitations under which United States forces will initiate and/or continue combat engagement with other forces encountered." ROE are used by States to tailor the rules for the use of force to the circumstances of a particular operation. ${ }^{24}$

ROE may vary between states and the military forces of each state, even if acting together (e.g. in alliance or a coalition) will adhere to their own national laws and policies. As such, ROE may contain restrictions and/or amplifying instructions (e.g. regarding the concepts of personal self-defence or defence of property, in so far as these are relevant) in order to ensure compliance with such laws and policies. ${ }^{25}$ Crucially (and as discussed further below), such national caveats may not exceed the limits posed by international law. ${ }^{26} \mathrm{ROE}$ therefore form one part of the package of domestic and international laws, regulations and policies that govern how the forces of a state operate in a military context at any given time. ROE are important as they describe key elements of the rules governing the use of force by states and their armed forces, what state policy is regarding such use of force and how that is effected in practice. As examples of state practice therefore, they are especially pertinent to the current analysis.

A state's ROE often explicitly affirm the right of personal and unit self-defence. However, being an inherent right, the ability for both individual servicemen and military units to defend themselves operates quite independently from ROE and may not be limited by

\footnotetext{
${ }^{22}$ Gill and Fleck (n 7) 228.

${ }^{23}$ UK Ministry of Defence, The Manual of the Law of Armed Conflict (Oxford University Press 2005) (UK Law of War Manual) para 5.2.

${ }^{24}$ US Department of Defense, Law of War Manual, June 2015 (Updated May 2016), available at $<$ http://www.defense.gov/Portals/1/Documents/DoD_Law_of_War_Manual-

June_2015_Updated_May_2016.pdf> (US Law of War Manual) para 1.6.5, citing Joint Publication 1-04, Legal Support to Military Operations (Aug. 17, 2011) GL-3.

${ }^{25}$ Gill and Fleck (n 7) 231.

${ }^{26} \mathrm{Ibid}$
} 
them. ${ }^{27}$ As such, state ROE invariably recognize that nothing in the ROE limits or negates the right of individual or unit self-defence. ${ }^{28}$ They thereby entrench this inherent right in the context of military operations. In addition, they constitute transmission mechanisms, whereby the right of personal and unit self-defence (generally recognized as a matter of state policy and practice) and national self-defence are linked. This is discussed further below.

For some states, the right of a unit commander to defend their unit (and other units from their state) in the face of an attack or imminent attack is also expressed in the ROE as an obligation. ${ }^{29}$ In 2005 for example, the United States Chairman of the Joint Chiefs of Staff issued Standing Rules of Engagement (SROE) that applied to all United States military operations worldwide. ${ }^{30}$ The SROE explicitly sets out that:

$[\mathrm{u}]$ nit commanders always retain the inherent right and obligation to exercise unit selfdefense in response to a hostile act or demonstrated hostile intent. Unless otherwise directed by a unit commander as detailed below, military members may exercise individual self-defense in response to a hostile act or demonstrated hostile intent. ${ }^{31}$

To ensure that military personnel are clear about their ability to defend themselves, in addition to any training that they receive, ROE cards may be handed out to them to be carried during operations. They often contain explicit wording that emphasises their inherent right. This wording is sometimes in bold capitals at the top of the card, thereby highlighting its importance. Examples from the US include: 'Nothing in these rules prohibits our forces from exercising their inherent right of self defense,' and 'You always have the right to use necessary and proportional force to defend yourself' ${ }^{32}$

\footnotetext{
${ }^{27}$ Gill and Fleck (n 7) 481, 498.

${ }^{28}$ Hosang (n 7) 31, 52; Trumbull (n 21) 121. Whilst this paper is limited to a discussion of the disconnect between the right of national self-defence and that exercised by individuals or units, such explicit recognition is also found in ROE issued by certain international organizations and is likewise contained in ROE pertaining to UN peacekeeping operations. An obvious example of an international organisation that employs ROE is NATO. NATO ROE normally explicitly recognize that: [i]ndividuals and units have an inherent right to defend themselves against attack or an imminent attack, and NATO ROE issued for a mission do not limit this right. Because national laws differ, there will not always be a consistency between multinational forces as to where the right to use force in self-defence ends and the use of force authorized by the mission ROE begins. (...) In cases of inconsistency, the mission's ROE shall not be interpreted as limiting the inherent right of self-defence. Sherrod Bumgardner et al, NATO Legal Deskbook ( $2^{\text {nd }}$ edn 2010), available at <https://info.publicintelligence.net/NATO-LegalDeskbook.pdf>, 259. For UN Peacekeeping missions and the right of self-defence, see e.g Trumbull (n 21) 129, 134, 138-9; Hosang (n 7) 49-51; Gill and Fleck (n 7) 170-80, 478-9.

${ }^{29}$ See Sanremo Handbook, para 8(b).

${ }^{30}$ Chairman of The Joint Chiefs of Staff Instruction, CJCSI 3121.01B, Standing Rules of Engagement/Standing Rules For The Use Of Force for U.S. Forces (13 June 2005) (US SROE 2005), available at $\langle$ http://www.jag.navy.mil/distrib/instructions/CJCSI\%203121.01B13Jun05.pdf >.

${ }^{31}$ US SROE 2005, para 6(b)(1) (emphasis added).

${ }^{32}$ US SROE 2005, Appendix B, 'Sample ROE Cards'. The first set of wording comes from a 'peace enforcement' operation carried out by KFOR in Albania in April 1999. The second was an armed conflict 'stability operation', being Operation Iraqi Freedom in 2005. Likewise, each of the model ROE cards in the Sanremo Handbook, Appendix 4 to Annex C, confirm that 'nothing in your role limits your right to take action in self-defence.' This wording is in bold capitals and appears at the top of each ROE card.
} 


\section{Issues and Disconnects}

State practice, often expressed via ROEs, generally and explicitly recognizes and affirms both the right of individual and unit self-defence. Such right is put at the very centre of the rules pertaining to the use of force by states through their military apparatus. This is recognized as a matter of national policy that extends from the highest levels of governmental or executive authority all the way down the chain of command to the individual soldier, sailor or airman. Even if ROE are not used by states, international law recognizes that self-defence operates as a cardinal principal to be called upon by individuals to safeguard life and, in certain instances, property. Whilst this position seems perfectly clear and relatively uncontroversial at the personal and unit level, when the state perspective is brought into the equation, the effective operation of international law encounters a number of stumbling blocks.

\section{i. A distinction been national, unit and personal self-defence?}

The first question when addressing the issue of national self-defence and personal and unit self-defence is whether they are all one and the same thing or separate and distinct concepts. The question, whilst little analysed, is a crucial one. It determines how and when a state has the right to act in self-defence as a matter of law and also whether it is acting in self-defence as a matter of fact. It further determines when the obligation to report exercises of the right of self-defence to the UNSC is triggered. ${ }^{33}$

Few jus ad bellum scholars have touched upon this issue. This is in contrast to military lawyers, who are closer to the operational end of the consequences of any conceptual separation and for whom any distinction is crucial. As noted above, where the separation issue is discussed, the focus tends to be on the unit, rather than individual military personnel. The international law analysis however, in terms of the link between the different levels of self-defence, is the same for both. Dinstein is one of those rare jus ad bellum commentators to express an opinion on the point from that perspective. For him, whilst the labels of 'unit selfdefence' (which he calls 'on-the-spot reactions') and 'national self-defence' are useful to 'pin the authority and the responsibility for specific action on diverse echelons (...) this bifurcated phraseology is apt to be misleading in the context of the international law of armed conflict. ${ }^{34}$ In Dinstein's opinion, there is a quantitative, but no qualitative, difference between a single unit responding to an armed attack and the entire military structure doing so. ${ }^{35} \mathrm{On}$ this unitary view, self-defence is always exercised by the state. It follows therefore that the actions of the senior general or admiral are equivalent to the actions of the lowest ranking unit-commander for the purposes of attribution of conduct to the state (see section III.ii below) ${ }^{36} \mathrm{He}$ concludes that '[o]nce counter-force of whatever scale is employed by military units of whatever size - in response to an armed attack by another State - this is a

\footnotetext{
${ }^{33}$ Art 51 UN Charter requires that '[m]easures taken by Members in the exercise of this right of self-defence shall be immediately reported to the Security Council'.

${ }^{34}$ Yoram Dinstein, War, Aggression and Self-Defence (Cambridge University Press, 5th edn 2011) 243.

${ }^{35} \mathrm{Ibid}$

${ }^{36}$ Ibid
} 
manifestation of national self-defence, and the legality of the action is determined by Article 51 as well as by customary international law.' ${ }^{37}$

Dinstein's position is in line with the premise that unit self-defence is a manifestation of the right of national self-defence, whereby military units represent the state to which they belong. Such an idea is long espoused in international law. Vattel for example recognized that the military and the state are one: ' $[\mathrm{t}]$ he sovereign is the real author of war, which is carried on in his name, and by his order. The troops, officers, soldiers, and, in general, all those by whose agency the sovereign makes war, are only instruments in his hands. They execute his will and not their own. ${ }^{38}$ Adopting this position means that an attack on the military unit equates to an attack on the state itself. Gill and Fleck also subscribe to this approach. For them, ' $[t]$ he right to unit self-defence is primarily derived from the right of national selfdefence, combined with the status of military units as representatives of the sovereign rights of the State in question. ${ }^{39}$ Unit self-defence is therefore a 'unit-level representation' of the national right of self-defence. ${ }^{40}$

A number of military lawyers, most notably from the United States (but also elsewhere), have rejected the interpretation that unit self-defence is a low-level version of national selfdefence. Hosang for example asserts that it is 'undesirable from a political and operational view' that units effectively have the authority to trigger national self-defence. ${ }^{41}$ However, this is expressed as a matter of policy, rather than legal doctrine. He concludes that unit selfdefence is a 'localized exercise of self-defence and is not necessarily a starting point for a nation-wide response in national self-defence.' ${ }^{42}$ Trumbull also rejects the unitary interpretation, arguing that national and unit self-defence are distinct and the right of unit selfdefence may be triggered even where the right of national self-defence is not. ${ }^{43}$ In reaching this conclusion, he notes, inter alia, that states also make a distinction between the two. The Sanremo Handbook (which he relies on as one example of state practice on this point) indeed distinguishes between individual self-defence, unit self-defence and national self-defence. The former two are said to be decisions made on the micro level, whereas the latter is at the

\footnotetext{
${ }^{37}$ Ibid. Whilst this statement is expressed to apply to unit self-defence, given his preceding comment pertaining to attribution, it seems that his analysis and conclusion would apply equally to individual military personnel as well as to units. This conclusion is supported by the application of the rules of attribution as set out in section III.ii below and is the approach that this paper adopts. In addition, his opinion is expressed to apply to an armed attack 'by another State'. Given his acceptance of a right of self-defence against armed attacks by NSAs operating from foreign territory, it is also assumed that the same logic would also apply to such armed attacks by NSAs. Ibid, 269-70.

${ }^{38}$ Emer de Vattel, The Law of Nations, Or, Principles of the Law of Nature, Applied to the Conduct and Affairs of Nations and Sovereigns (1797, reprinted, Indianapolis: Liberty Fund, 2008), Book III, Chapter II, §6.

${ }^{39}$ Gill and Fleck (n 7) 482.

${ }^{40} \mathrm{Ibid}, 483$.

${ }^{41}$ Hosang (n 7) 52.

${ }^{42}$ Ibid, 53, 57-8.

${ }^{43}$ Trumbull (n 21), in particular 126-133, 147. Stephens (n 6) takes a similar view. See also Corn (n 9). This paper attempts to address some of the main arguments put forward by such commentators that national selfdefence, as governed by the jus ad bellum (comprising Art 51 UN Charter and applicable customary international law), is legally separate from the right of personal and/or unit self-defence.
} 
macro level, invoked and retained at 'the highest levels of governmental or executive authority'. ${ }^{44}$

The conclusion by such lawyers that there is a distinction to be made between levels of self-defence seems hard to sustain when one considers the role of ROE in the equation. In circumstances where ROE explicitly recognize the inherent right of individual and/or unit self-defence, then this is a national decision, as taken at the highest levels of government or executive authority. It is therefore an expression of national policy that is transmitted all the way down the chain of command to all military personnel. In and of itself, such state practice provides a unitary approach to the right of self-defence, even if the exercise of that selfdefence may occur at the level of the state (as a whole) or on a localised or individual basis. Those who fear that this approach means that minor or localised uses of defensive force might engage a wider national level response fail to recognize that international law possesses appropriate tools to address this concern. Ensuring that self-defence (whether it be at a state or personal/unit level) is actually required in the circumstance and, if so, is reasonable in terms of its scale, scope, duration and intensity, are matters for the customary requirements of necessity and proportionality. Even if the scope and content of these requirements are controversial and require further clarity, they are the correct tools to monitor and constrain all uses of defensive force. Bifurcating the law of self-defence does not properly address this issue.

Yet, for some military lawyers, a unitary view of self-defence raises fundamental concerns for how units defend themselves. One subject of controversy is the Nicaragua gravity threshold, which relates to the trigger of the right of self-defence and is discussed in detail in section III.iii below. Another is the aforementioned question regarding the level at which the decision to effect the right of national self-defence is taken. The ability for unit commanders to bring about the exercise of this right is viewed as hugely problematic to a unitary conception of self-defence. Prima facie, this concern appears justifiable. There is good reason to distinguish between the exercise of the right (once it is triggered) at the different levels. At the state level, the exercise of the right of national self-defence (being if, when and how to respond defensively) is essentially political, albeit that such decision is (or should be) taken in accordance with the law. It will involve any number of different considerations, involving aspects of foreign policy, national security and possible constitutional requirements. ${ }^{45}$ In contrast, at the individual or unit level, different consideration will apply and the decision to respond or not to armed aggression is likely to be more immediate. ${ }^{46}$ The concern that this latter response somehow pulls the state into a situation of national self-defence, perhaps against its political will, is easily addressed however. As Gill and Fleck rightly note, unit self-defence is a tactical-level right (what this paper refers to as the 'micro level' of action), whereas the right of national self-defence is a strategic-level right (what this paper refers to as the 'macro level' of action). On this basis:

\footnotetext{
${ }^{44}$ Sanremo Handbook, para 8(d).

${ }^{45}$ Gill and Fleck (n 7) 483.

46 ' $[\mathrm{T}]$ he trigger event being defended against at the unit level will be more immediate, of smaller scale than an attack on a nation as a whole, and require an immediate response.' Ibid
} 
[u]nit commanders need not have the authority to order the entire military assets of his nation to respond to the attack as if the nation was under attack but merely needs to have, and has, the authority to defend his unit against the attack on his or her unit. Similarly, an attack on a unit does not ordinarily lead to an activation of all the national self-defence responses in the nation whose unit is under attack, but will usually be only a piece in a larger composition of events and circumstances that define the national security situation at the time in question. ${ }^{47}$

What happens at the unit level therefore may or may not, as a factual matter, have ramifications for a wider state response. There is a caveat to this truism however. Despite the factual issue of whether self-defence is being exercised at the macro or micro level, the correct legal characterisation of exercises of self-defence at both levels remains as 'national self-defence'. This is primarily because of the rules of attribution.

\section{ii. Attribution}

It is international law relating to state responsibility and attribution that constitutes the most significant issue for the commentary and jurisprudence on the issue of self-defence and the disconnects that arise from them. It is also the factor that ultimately defeats any suggestion that national and personal/unit self-defence are distinct and separate concepts. The starting point when looking at this issue is a simple, but foundational, premise. This is that '[s]tates can only act by and through their agents and representatives. ${ }^{48}$ This self-evident fact is fundamental to the analysis of the right of national self-defence. Furthermore, it is a 'wellestablished rule of [customary] international law [that] the conduct of any organ of a state must be regarded as an act of that state. ${ }^{49}$ Such rule is codified in Article 4 ARSIWA. ${ }^{50}$ Article 4 provides:

1. The conduct of any State organ shall be considered an act of that State under international law, whether the organ exercises legislative, executive, judicial or any other functions, whatever position it holds in the organization of the State, and whatever its character as an organ of the central government or of a territorial unit of the State.

2. An organ includes any person or entity which has that status in accordance with the internal law of the State.

\footnotetext{
${ }^{47} \mathrm{Ibid}$

${ }^{48}$ German Settlers in Poland (1923) PCIJ Rep Series B No 6, 22.

${ }^{49}$ Difference Relating to Immunity from Legal Process of a Special Rapporteur of the Commission on Human Rights, [1999] ICJ Rep 62, para 62 (emphasis added).

${ }^{50}$ International Law Commission Articles on Responsibility of States for Internationally Wrongful Acts, with Commentaries, in Report of the International Law Commission on the work of its fifty-third session, UN Doc A/56/10 (2001) (ARSIWA).
} 
For the purposes of Article 4, it is clear that an organ exercising 'executive functions' includes the military forces of the state. Indeed, as Crawford notes, '[ $\mathrm{t}]$ he most obvious executive manifestations are actions of the armed forces, which in the context of armed conflict are in all cases attributable to and engage the international responsibility of the state in question. ${ }^{51}$ This applies not only to the military forces as a whole, but also to the conduct of individual servicemen and officers, whose individual acts are to be considered the conduct of a state organ. ${ }^{52}$ The result is that states are responsible for all acts of their armed forces, regardless of whether they acted contrary to their instructions or exceeded their authority. ${ }^{53}$ Ultimately, the military and the state are one.

Notably, Hosang, Trumbull and other adherents who maintain a distinction between unit and national self-defence fail to address this crucial legal point. The better view therefore, from the perspective of international law, is that the distinction between unit and national selfdefence is purely descriptive. It should not be viewed as a legal distinction. In fact, the Sanremo Handbook clearly offers a description of the various types of self-defence for the purposes of the Handbook, rather than an assertion as a matter of law, that the types of selfdefence are in any way legally distinct. ${ }^{54}$ Despite the unitary legal position however, it is admittedly useful to have labels that include 'national self-defence', 'personal self-defence' and 'unit self-defence'. We may talk of them separately in this way and this paper employs these terms throughout. However, the distinction is purely expository. It speaks to the factual circumstances of the particular act of self-defence and refers to issues of locality and scale. As such, an act of self-defence may be minor and localised, involving a few military personnel or a small unit in an exchange of fire that is contained and quickly over. Confined to this locality and scale, there may be no need for additional military units or personnel to be involved. Any further commitment of resources is at the option of the state; subject always to the requirement that whatever defensive force is used is both necessary and proportionate. As a factual matter such an 'on-the-spot reaction' might quite properly be labelled, depending on the circumstances, as an act of personal or unit self-defence. If the incident escalates however, requiring a wider response involving additional military apparatus of the state and strategic decisions at higher levels of government or military command then, factually, this may be more properly called national self-defence. Yet, drawing a legal distinction between these scenarios ignores the operation of international law. It falls foul of the rules of state responsibility and attribution. The view of Dinstein and Gill and Fleck is therefore to be

\footnotetext{
${ }^{51}$ James Crawford, State Responsibility: The General Part (Cambridge University Press 2013) 119. See also Gill and Fleck (n 7) 561.

${ }^{52}$ Case Concerning Armed Activities on the Territory of the Congo (Democratic Republic of the Congo $v$ Uganda) (Judgment) [2007] ICJ Rep 168, para 213-14.

${ }^{53} \mathrm{Ibid}$, para 214. See also Hague Convention IV Respecting the Laws and Customs of War on Land (adopted 18 October 1907, entered into force 29 January 1910) 205 CTS 277, Art 3; Protocol Additional to the Geneva Conventions, 12 August 1949, and Relating to the Protection of Victims of International Armed Conflicts (adopted 8 June 1977, entered into force 7 December 1978) 1125 UNTS 3, Art 91.

${ }^{54}$ The Sanremo Handbook, para 8, merely states that '[f]or the purposes of this Handbook, the right of selfdefence is considered on four levels' (emphasis added), before going on to list and describe four types of selfdefence.
} 
preferred. This means that, legally, each of these examples will (also) be national selfdefence, and subject to the rules of the jus ad bellum.

In order to demonstrate how attribution operates in respect of the current self-defence analysis, let us take the example of a small group of soldiers belonging to state A that are manning a border post between states A and B. There is no on-going or recent war or other uses of force between the two states. One day, out of the blue, a handful of armed soldiers belonging to state $\mathrm{B}$ appear on the other side of the border and start firing at the state $\mathrm{A}$ soldiers. No one could deny that the state A soldiers, both individually and as a unit, have a prima facie right to defend themselves against such an unlawful use of force. Their ROE may even require such defence (as in the case of US SROE 2005). What is the position of 'the state' however in this scenario? Does it have the lawful right to defend itself under Article 51 UN Charter and what does is actually mean in these circumstances to say that the 'state' is defending itself?

The scenario, which resembles a 'mere frontier incident' in the Nicaragua sense, raises a number of factual and legal issues. ${ }^{55}$ Factually in these circumstances, the right of individual and/or unit self-defence does transpose itself into national state defence. State A is de facto defending itself. This is because the acts of the state A soldiers are attributable to state A under Article 4 ARSIWA. This assumes that the soldiers are part of the regular army and, therefore, are organs of the state. If they are irregular troops, then their acts are also attributable to state $\mathrm{A}$ if they are acting on the instruction of, or under the direction or control of, state A. ${ }^{56}$ In both instances, this is the case even if the defensive response by the individual servicemen or unit is considered ultra vires as being in excess of authority or contravening instructions. ${ }^{57}$ For example, if the act of self-defence was in breach of any limitations imposed by their ROE. ${ }^{58}$ This de facto position counters the suggestion that, de jure, the military forces of a state are somehow separate from the state itself. ${ }^{59}$ It also acts as a rebuttal to the notion that the exercise of national self-defence is ultimately a political decision, one made by the national (political) command authorities at the state level. ${ }^{60}$ Whilst this may be a

\footnotetext{
${ }^{55}$ For discussion of 'mere frontier incidents' and the impact of the Nicaragua gravity threshold on the rules of attribution, see section III.iii.

${ }^{56}$ ARSIWA, Art 8. See further Crawford (n 51) 144-156.

${ }^{57}$ ARSIWA, Art 7.

${ }^{58}$ If the acts of the soldiers are in a private capacity however, the analysis is different. For Article 4 attribution, the test is whether the soldiers' actions were 'carried out by persons cloaked with governmental authority'. Petrolane, Inc. v. The Government of the Islamic Republic of Iran (1991), Iran-U.S. C.T.R. vol. 27, 64, 92. If their conduct is so removed from the scope of their official functions then it should be assimilated to them as private individuals and not attributable to the state. Commentary to ARSIWA, Art 7, para 7. This is a different question to whether the acts were ultra vires and ultimately requires an objective assessment of whether the soldiers' conduct is official (or appears to be official) or is private.

${ }^{59}$ Stephens (n 6) 136, believes that ' $[\mathrm{t}]$ he right of unit self defense is one which attaches to the military forces of a State. Consequently, unit self defense should be distinguished from the right to act in national self defense which is exercised by the State itself.' As noted, whilst this assertion may be correct as a matter of descriptive fact, legally it fails because of the rules of attribution.

${ }^{60}$ Hosang (n 7) 42. Trumbull (n 21) 128 , in agreeing with this position, similarly suggests that '[i]t would be dubious to claim that every single soldier has the ability, much less the obligation, to exercise a right reserved to the nation.' Whilst this may be a valid policy argument, neither commentator addresses the de jure argument, taking into account attribution and the de facto position set out here.
} 
desirable as a matter of policy and may often be the case, our scenario shows that this will not always be true. This view simply does not square with the way in which attribution works. Neither does it take account of those ROE that, in recognising the inherent right of personal and unit self-defence, constitute an expression of state policy. Where this is so, the political decision has already been made that the right of self-defence is exercisable at the micro level. It is therefore wrong to suggest that individual or unit self-defence is merely a localized exercise of self-defence and not necessarily a starting point for a state level response in national self-defence. ${ }^{61}$

The laws of state responsibility mean that, for the purposes of the right of self-defence, the state and its armed forces are treated as one and the same thing. ${ }^{62}$ Where soldiers, sailors or airmen defend themselves therefore, the state will always be defending itself. However, the reverse is not always true. A state's right of national self-defence may well be triggered without triggering a particular individual's or unit's right. The right of national self-defence may arise as a result of an armed attack that is well away from, and have no connection with, any number of military personnel and units. Likewise, if the decision is taken at the national level to exercise the right of national self-defence that has arisen, this may have no bearing whatsoever on particular parts of the military that are not involved with the defensive response and will therefore not impact on their defensive rights. Attribution therefore only works up the chain of command and not down it.

At this point, it should also be noted that there is a distinction to be made between the right of self-defence arising and the right being exercised. At the national level, whether a state exercises the right (and/or chooses to expressly invoke that right publicly) will always be at the state's discretion. However, an interesting caveat to this general rule is where ROE (such as US SROE 2005) place an obligation on unit commanders to exercise their right of unit self-defence. In such circumstances, this could be interpreted as a state, by way of its own national policy, fettering its discretion to exercise its national right of self-defence. Because of the rules of attribution, when a unit commander complies with this obligation to defend their unit, the result is that the state is de facto defending itself, even if factually this may be regarded as a localized incidence of unit self-defence.

\footnotetext{
${ }^{61}$ Hosang (n 7) 53.

${ }^{62}$ In the context of international criminal law, this is not the case and there is a distinction between the state and the individual. Art 31(1)(c) Rome Statute for example recognizes that a person shall not be individually criminally responsible if, at the time of that person's conduct, ' $[\mathrm{t}]$ he person acts reasonably to defend himself or herself or another person or, in the case of war crimes, property which is essential for the survival of the person or another person or property which is essential for accomplishing a military mission, against an imminent and unlawful use of force in a manner proportionate to the degree of danger to the person or the other person or property protected. The fact that the person was involved in a defensive operation conducted by forces shall not in itself constitute a ground for excluding criminal responsibility under this subparagraph' (emphasis added). Whilst the Rome Statute therefore recognizes that the state and the individual are distinct and that the exercise of national self-defence does not necessarily excuse conduct at the individual level, this is in the situation where an individual is raising a defence to an accusation of a crime. It does not relate to attribution for the purpose of establishing a right of national self-defence, which is very different, and it should not be used to suggest otherwise. $C f$ Trumbull (n 21) 127-8.
} 


\section{iii. $\quad$ The Nicaragua gravity threshold}

A well-known debate exists in the jus ad bellum that seriously affects how self-defence works from both the state perspective and at the level of the individual or unit. As noted above, one issue with taking a unitary view of self-defence relates to the point at which the right of selfdefence is triggered. The reason that this is problematic is due to the effect of a key ICJ decision that relates to this trigger.

In Nicaragua, the ICJ introduced a de minimis threshold into the law governing the right of national self-defence. ${ }^{63}$ In assessing whether an armed attack had occurred, the Court stipulated that it was necessary to distinguish between 'the most grave forms of the use of force (those constituting an armed attack) from other less grave forms' ${ }^{64}$ Whilst the debate over this dictum is well known, it is useful for the present analysis to highlight the main controversies, before addressing how personal and unit self-defence fit into the picture. First, the distinction is important as, according to the Court, 'less grave' uses of force, even if they constitute a breach of Article 2(4) UN Charter, do not trigger the right of self-defence on the part of the victim state. If the aggressor is a state, its international responsibility will be engaged by such uses of unlawful force. ${ }^{65}$ However, the only lawful response by the victim state to these lesser attacks, other than dispute resolution or raising the matter with the UNSC (that has the right to authorise the use of force under Chapter VII UN Charter), will be to use countermeasures against the aggressor. Importantly, such countermeasures may not involve the threat or use of force. ${ }^{66}$

The dilemma regarding when the right of national self-defence arises is where the line should be drawn between the 'most grave' and the 'less grave' uses of force. The position is unclear. The ICJ in Nicaragua did refer to the necessary 'scale and effects' of military action that were required to reach the threshold of an armed attack. ${ }^{67}$ It did not elaborate further however, other than to hold that 'mere frontier incidents' would not satisfy this requirement. ${ }^{68}$ This part of the Nicaragua judgment has been criticised on a number of grounds. ${ }^{69}$ For the purposes of this paper however, the requirement of a gravity threshold also poses an interesting conundrum for a unitary view of self-defence and how the operation of the right at

\footnotetext{
${ }^{63}$ The case concerned an alleged armed attack against a state, although see below regarding comments made by the Court that may have bearing on the right of unit self-defence.

${ }^{64}$ Nicaragua, para 191. This was upheld in Case Concerning Oil Platforms (Iran v US) (Judgment) [2003] ICJ Rep 161 (Oil Platforms) para 51. The same approach was adopted by the Eritrea Ethiopia Claims Commission in Jus Ad Bellum Ethiopia's Claims 1-8 between The Federal Democratic Republic of Ethiopia and The State of Eritrea, Partial Award, 19 December 2005, 45 International Legal Materials (2006) 430 (Eritrea-Ethiopia Claim). The Commission held, at para 11, that '[1] ocalized border encounters between small infantry units, even those involving the loss of life, do not constitute an armed attack for purposes of the Charter.' No further reasoning or explanation was given on this point however.

${ }^{65}$ ARSIWA, Art 1.

${ }^{66}$ ARSIWA, Art 50(1)(a). See below however regarding the Court's reference to proportionate forcible countermeasures.

${ }^{67}$ Nicaragua, para 195.

${ }^{68}$ Ibid

${ }^{69}$ See e.g. John Lawrence Hargrove, 'The Nicaragua Judgment and the Future of the Law of Force and SelfDefence" (1987) 81 American Journal of International Law 135; William Taft, "Self-Defense and the Oil Platforms Decision’ (2004) 29 The Yale Journal of International Law 295, 300-2; Dinstein (n 34) 207-212.
} 
the state level relates to the right of self-defence of military personnel and units. A gravity threshold for national self-defence sits uncomfortably with the non-derogable personal and unit right of self-defence. The latter do not require a particular threshold of violence to be crossed before they are exercisable. Instead, as noted, the right of personal and unit selfdefence arise in response to an unlawful use of force. As such, border incidents, however minor, may well give rise to the right of individuals and units to defend themselves and, potentially, property. If there is loss of life or damage to property, then the specific geographical locale (e.g. being along a border) seems irrelevant to this determination.

How then may this fact be reconciled with the ICJ jurisprudence? It has been suggested that because unit self-defence will generally be required in the context of a 'frontier incident', the very circumstance in which the Court has proscribed the use of national self-defence, this dictum reduces the concept of unit self-defence to a nullity. ${ }^{70}$ Yet, presumably the Court did not deliberately intend to strip the right of self-defence from military personnel and units. At least, if it had this intention, it did not express it explicitly. However, neither did it identify personal or unit self-defence as an exception to its ruling. There is no suggestion therefore that either constitutes an independent additional exception to the Article 2(4) ban on force. ${ }^{71}$ The result is a confusing disconnect between the macro level and micro level and raises a troubling question regarding when the right of national self-defence may be triggered. Border incidents have been recognized as being severe enough to lead directly to claims of national self-defence, even if this claim has been subsequently rejected. ${ }^{72}$ For the right of self-defence to exist at the micro level for military personnel and units in response to 'less grave' uses of force (assuming that Nicaragua did not in fact extinguish this right), but not at the macro level for national self-defence, seems incongruous and unjustifiable. If the individual serviceman (of whatever rank) faces low-level violence, then the necessity of self-defence arises and they will generally be permitted as a matter of personal and/or unit self-defence to exercise it. ${ }^{73}$ As he is an organ of the state, then this necessity of self-defence is also that of the state 'as a whole'. The attack against him is an attack against the state. This allows the state, as a whole, to exercise this right of self-defence. As noted, regardless of the level of violence, when the individual (or unit) exercises the right, this act is transmitted upwards, via the rules of attribution, so that the state (as a whole) is de facto exercising that right.

\footnotetext{
${ }^{70}$ Stephens (n 6) 127, 138-40. It is partly because of the ICJ's decision on this issue and the potential limits that are consequently placed on the right of unit self-defence, that Stephens argues that unit self-defence is separate to national self-defence. Trumbull, n 21, 143-5, likewise suggests that recognizing a distinction between unit and national self-defence mitigates against the gravity threshold concern. He suggests that a unit (and presumably an individual) would have the right to defend himself in the case of frontier incidents falling below the level of an armed attack, even if the state's right of self-defence is not engaged (due to there being a lack of an armed attack). Neither commentator addresses the rules of attribution however. In addition, if accepted, such distinction introduces an additional exception to the Art 2(4) UN Charter ban on the use of force, which is both unwarranted and undesirable.

71 See $n 77$ below and accompanying text however regarding the prospect of proportionate forcible countermeasures not amounting to an exercise of self-defence.

${ }^{72}$ E.g. as in the Eritrea-Ethiopia Claim.

${ }^{73}$ Although the exercise of the use of force in personal self-defence may be the subject of further military direction as set out in the ROE, e.g. types of weapons authorized for use or 'hold fire' orders from their commander. Gill and Fleck (n 7) 232. See further n 119 regarding restrictions placed on the right of self-defence.
} 
The disconnect created by the gravity threshold poses a further dichotomy for the rules of attribution that appears to have been largely overlooked. This can be explained by going back to the scenario set out in the section above relating to the use of force between states A and B. At the micro level, the state A soldiers and their unit will have a right to defend themselves regardless of the scale of the violence directed at them, provided that the state B soldiers' use of force is unlawful. In the scenario as set out, this is assumed due to the surprise nature of the attack and no previous history of violence between the two states that would give rise to a legitimate claim of self-defence on the part of state B. At the jus ad bellum level however, the legal regime is different. If we accept the Nicaragua gravity threshold requirement, state A's right of national self-defence (that is actually being exercised by the state A soldiers) is conditioned on the attack by state B's soldiers reaching the required level of gravity (whatever that might be). Our scenario resembles a 'mere border incident' however and might fall below this threshold. If it does, the bizarre result is that the legitimate and lawful acts of the defending soldiers and/or unit do not translate into a lawful right of self-defence on the part of the state. Instead, by defending their own lives, the individual state A servicemen might engage state A's international responsibility for an internationally wrongful act. Applying Nicaragua's dictum potentially means that no right of national self-defence arises that would preclude the wrongfulness of state A's use of force. The ICJ in Nicaragua thereby created a disconnect between the two levels of self-defence that result in a curious outcome for the laws of state responsibility. Despite the fact that the rules of attribution mean that, de facto, a state will always be defending itself when its military defend themselves (and will be responsible de jure for those acts of self-defence), the de jure picture regarding when the right to do so arises is fractured. Whether or not the ICJ considered such a result in deciding Nicaragua is uncertain, but the consequence is an avoidable obfuscation of the law. The threshold means that the laws on state responsibility do not work in a cohesive manner with the jus ad bellum.

In terms of when the right of national self-defence is triggered therefore, when we consider the personal and unit perspectives, whether the gravity threshold has any true substantive meaning is cast into considerable doubt. That a right of national self-defence is only triggered in respect of a particular, unspecified level of violence appears hard to maintain on closer examination. The legal analysis (or lack thereof) undertaken by the ICJ and the Eritrea Ethiopia Claims Commission on this point has lead to a disconnect between the two levels of self-defence and a fragmentation of the jus ad bellum and international law more generally. From the perspective of international law, there is no conceptual or principled reason why different rules should apply to national self-defence and to personal/unit selfdefence. The legal analysis should be one that views the situation as whole, rather than distinguishing between two distinct levels. If the soldiers' acts on the ground are necessary and proportionate and therefore lawful, then this should also 'whitewash' the act of national self-defence so that it is also lawful. That this may not be the case leaves states and their military forces in very difficult territory. Singling out 'less grave' 'mere border incidents' for special treatment, without first clarifying what those terms mean and specifying how they relate to individual and unit self-defence and rules of state responsibility and attribution is unsatisfactory and potentially leads to unjustifiable results. The fact that the assessment as to whether there has been an armed attack is made ex post facto by a court or tribunal raises the risk of a disconnect between legal theory (as propounded by judicial examination) on the one 
hand and on the ground operational reality or real world political or military judgement on the other. It also does not take into account ROE which, as examples of state practice, tend to recognise expressly the right of individual and unit self-defence, without specifying any threshold of gravity. These issues serve to reinforce the fact that the distinction between grave and less grave uses of force is unnecessary. They cast doubt as to whether the threshold principle can be logically applied in practice and may therefore contribute to an effective limitation on the right of self-defence.

If the policy concern that the introduction of the gravity threshold seeks to address is the risk of escalation of violence, then such apprehension is valid and important. Minor skirmishes may result in more widespread violence. Equally however, they may fade away, resulting in a one-off and minor 'on-the-spot' reaction (to coin Dinstein's phrase). ${ }^{74}$ In either case however, and as already noted, international law provides rules for an appropriate response, whether on a small or large scale. The application of defensive force by both the state as a whole and by individual military personnel and their units has to be both necessary and proportionate (see section III.v below). These requirements restrain and contain a use of defensive force. The concern is not addressed appropriately by the insertion into the jus ad bellum of an arbitrary rule that leads to absurd results once the rules are applied in practice. To the extent that defensive force is not objectively necessary or proportionate, it will be unlawful. ${ }^{75}$ In which case, the state (on the basis of state responsibility) and/or the individual (on the basis of individual criminal responsibility) is liable to be held accountable. If the concern with this approach is that necessity and proportionality are inherently malleable concepts and, therefore, applying them is too difficult, then this is a separate issue. It does not follow that they are the wrong tools to do the job of containing the defensive response. Instead, it is incumbent on states, court, tribunals and scholars to work to develop and clarify them, particularly in the jus ad bellum. We should not be content with the disconnect as it stands. The gravity of any attack is therefore better thought of as conditioning a proportionate defensive response, rather than defining an armed attack in the first instance. ${ }^{76}$ Such conclusion is only made stronger when the position of soldiers, sailors and airmen is considered as part of the equation.

There is a lack of conceptual consistency therefore in the ICJ's jurisprudence, with the Court seeming to limit its consideration to issues of national self-defence. One might argue that this is in line with the rule of ultra non petita. The Court, in cases involving issues of the use of force and self-defence, has simply not been called upon to consider specifically issues of personal or unit self-defence. There are no explicit dicta therefore to draw upon. Yet, arguably, consideration of such issues is part and parcel of the national self-defence calculus and therefore integral to any decision regarding what gravity of violence (if any) is required before the right of self-defence arises. The Court has implicitly touched upon this issue however on a couple of occasions, albeit in a very limited manner.

\footnotetext{
${ }^{74}$ Dinstein (n 34) 243.

${ }^{75}$ The ICJ has strongly rejected the notion that the determination of necessity lays within the state's discretion, even where acting in good faith. Instead, it has stipulated that the test of necessity is 'strict and objective, leaving no room for any "measure of discretion". Oil Platforms, para 73.

${ }^{76}$ Rosalyn Higgins, Problems and Process: International Law and How We Use It (Oxford University Press 1994) 251; Taft (n 69) 300.
} 
In Nicaragua, the majority seemingly left open the prospect for a state subject to a use of force (being of a lesser degree of gravity than an armed attack) to take proportionate forcible countermeasures (not amounting to self-defence) by way of response. ${ }^{77}$ Judge Simma in his dissent in Oil Platforms, certainly understood this to be the case and, in so doing, he appeared to specifically consider the position of the unit:

I would suggest a distinction between (full-scale) self-defence within the meaning of Article 51 against an "armed attack" (...) on the one hand and, on the other, the case of hostile action, for instance against individual ships, below the level of Article 51, justifying proportionate defensive measures on the part of the victim, equally short of the quality and quantity of action in self-defence expressly reserved in the United Nations Charter. ${ }^{78}$

Whilst by no means clear, the Court has at least contemplated tangentially the need for states to defend themselves at some sort of lower level, where the force being responded to does not meet the threshold of an armed attack. What this means in practice is anyone's guess. Regardless of the label attached to it, if this is not self-defence for the purposes of Article 51 UN Charter, then it is unclear how such force will not breach Article 2(4) UN Charter. As noted above, the modern understanding is that countermeasures may not involve the threat or use of force ${ }^{79}$ and, if not a countermeasure but rather a reprisal, then these are considered unlawful in peacetime. ${ }^{80}$

In Oil Platforms, the United States asserted a right of self-defence following the mining of the USS Samuel B. Roberts, which it argued was an armed attack attributable to Iran. ${ }^{81}$ What is noteworthy in this context is that the United States claimed such right in response to an armed attack on a military unit. In its Article 51 letter to the UNSC it set this out as follows:

In accordance with Article 51 of the Charter of the United Nations, I wish, on behalf of my Government, to report that United States forces have exercised their inherent right of self-defence under international law by taking defensive action in response to an attack by the Islamic Republic of Iran against a United States naval vessel in international waters of the Persian Gulf. ${ }^{82}$

In response to this claim, the Court could not exclude the possibility that the mining of a single military vessel might indeed be sufficient to engage the 'inherent right of selfdefence' ${ }^{83}$ This conclusion appears to relate to the right of national self-defence however,

\footnotetext{
${ }^{77}$ Nicaragua, paras 201, 210, 249. See further Dinstein (n 34) 208-9.

${ }^{78}$ Oil Platforms, Judge Simma, sep op, para 12.

${ }^{79}$ ARSIWA, Art 50(1)(a).

${ }^{80}$ Legality of the Threat or Use of Nuclear Weapons (Advisory Opinion) [1996] ICJ Rep 226 (Nuclear Weapons) para 46.

${ }^{81}$ Oil Platforms, Counter-Memorial and Counter-Claim Submitted by the United States of America (23 June 1997) para 1.113.

${ }^{82}$ UN Doc S/19791 (18 April 1988).

${ }^{83}$ Oil Platforms, para 72.
} 
given that it was made in respect of its determination that the United States had not been the subject of an armed attack. The Court did not offer any explicit thoughts on the right of unit or individual self-defence. Yet, this example recognizes that the unit is part of the equation for both the United State's claim of a right of self-defence and the Court's assessment of it. This approach (in terms of state practice on the subject) was repeated very recently when the United States, in targeting certain radar sites in Yemen, claimed a right of self-defence following reported missile launches that threatened the USS Mason whilst in international waters. ${ }^{84}$ The importance of the military unit to the assessment of the national right of selfdefence cannot be denied therefore, but how the ICJ will approach this issue in the future is unclear.

The Court's comment in Oil Platforms regarding the mining of a single military vessel suggests at least that the scale and effects required to cross the gravity threshold are low or that the threshold is better viewed as a hiatus. ${ }^{85}$ However, what is not apparent is whether the determining factor that means the gravity threshold is crossed is the laying of a single mine (being one act that, in itself, might be sufficient to constitute an armed attack), or whether it is the nature, importance or size of the vessel damaged or destroyed or perhaps the number of people killed or injured on-board. ${ }^{86}$ Are we therefore looking at the act or the consequences of the act to determine gravity? The ICJ jurisprudence provides no clear answers. What is apparent in such circumstances is that the right of unit self-defence will normally arise where an individual military vessel (being a military unit) is attacked or where individual lives of service personnel are taken or threatened. In fact, in Corfu Channel, the ICJ seemed to accept that individual ships might reasonably retaliate if fired upon. ${ }^{87}$ This comment was admittedly made in light of an Albanian shore battery having previously fired on British warships when passing through the North Corfu Channel. This meant that the ships in question were at 'action stations' when subsequently proceeding through the Channel. ${ }^{88}$ Even so, whilst appearing to recognise a right of unit self-defence (in response to what might be considered a 'less grave use of force'), the Court makes no reference to a gravity threshold or any other requirements when suggesting that the British warships had a right to retaliate if attacked. The jurisprudence lacks internal consistency therefore. What is needed in the case law is a holistic analysis of the full self-defence picture that encompasses how the state, unit and individuals may or may not respond to particular levels of violence. A consolidated review of the right of self-defence by the ICJ, from top to the very bottom, would be welcome.

\footnotetext{
${ }^{84}$ Statement by Pentagon Press Secretary Peter Cook on U.S. Military Strikes Against Radar Sites in Yemen (12 October 2016), U.S. Department of Defense, available at $<\underline{\text { http://www.defense.gov/News/News-Releases/News- }}$ Release-View/Article/972169/statement-by-pentagon-press-secretary-peter-cook-on-us-military-strikes-against>. ${ }^{85}$ Dinstein (n 34) 208.

${ }^{86}$ In this incident the United States claimed that ten American sailors were injured, one seriously, and the ship was damaged. UN Doc S/19791 (18 April 1988).

${ }^{87}$ The Court noted the fact that 'ships at action stations in order that they might be able to retaliate quickly if fired upon again' was not an unreasonable precaution. Corfu Channel (United Kingdom v Albania) (Merits) [1949] ICJ Rep 4 (Corfu Channel) para 89.

${ }^{88}$ Telegram from Commander-in-Chief, Mediterranean, to the Admiralty, $26^{\text {th }}$ October 1946, in Corfu Channel, Volume II Documents of the Written Proceedings, Reply Submitted under the Order of the Court of 26th March, 1948 by the Government of the United Kingdom of Great Britain and Northern Ireland, Annex 31 to No.5, 309.
} 
There is one further potential consequence of any gravity threshold requirement. In Nuclear Weapons, the ICJ affirmed that Article 6 of the International Covenant on Civil and Political Rights does not cease in times of war. As such, in principle, the right not arbitrarily to be deprived of one's life applies also in hostilities. ${ }^{89}$ Stephens maintains that this dictum supports the argument that the right of unit self-defence is a non-derogable human right. As such, states may not withhold from them the right of self-defence. ${ }^{90}$ Whether or not unit selfdefence constitutes an independent human right, there is much to be said about a state's 'responsibility to protect' ${ }^{91}$ individuals from harm. In the context of the 'unwilling and unable' debate, Trapp has rightly asserted that:

[s]tates not only have an obligation to respect rights, but to ensure respect for those rights. As regards the right to life and physical integrity, embodied in all international and regional human rights instrument $[\mathrm{sic}]$, individuals are entitled to expect that the state that exercises jurisdiction over them will not be the source of any existential threat, but equally that the state of jurisdiction will do everything within its capacity to protect them from any such existential threat, whatever its source. ${ }^{92}$

This general duty was recognized by the ICJ in Palestinian Wall, when the Court emphasised that Israel had 'the right, and indeed the duty, to respond in order to protect the life of its citizens. ${ }^{93}$ That a state's human rights obligations extend, at least in principle, to a state's military personnel, in this case acting extraterritorially, was recognized by the UK Supreme Court in Smith and others $v$ The Ministry of Defence. ${ }^{94}$

The human rights position raises a very interesting conundrum for states. If, by attempting to comply with the Nicaragua dictum, a state were to purport to restrict the right of unit or personal self-defence so that it was only exercisable in the face of 'most grave' uses of force, would this amount to an arbitrary deprivation of life if death were to occur as a result of some minor incident? Would the state be in breach of its human rights obligations to protect individual service personnel from an existential threat? If so, the question is whether the gravity threshold can have any real meaning in practice, so that it may lawfully require (i.e. without breaching a state's human rights obligations) individual military personnel or

\footnotetext{
${ }^{89}$ Nuclear Weapons, para 25 . The test of what is an arbitrary deprivation of life then falls to be determined by the applicable lex specialis, being IHL.

${ }^{90}$ Stephens (n 6) 144-8.

${ }^{91}$ Report of the International Commission on Intervention and State Sovereignty (ICISS), The Responsibility to Protect (2001) para 2.22.

${ }^{92}$ Kimberley N. Trapp, 'Actor-pluralism, the 'turn to responsibility' and the jus ad bellum: 'Unwilling or unable' in context' (2016) 2(2) Journal on the Use of Force and International Law 199, 209.

${ }^{93}$ Legal Consequences of the Construction of a Wall in the Occupied Palestinian Territories (Advisory Opinion) [2004] ICJ Rep 13, para 141 (emphasis added).

${ }^{94}$ Smith and others $v$ The Ministry of Defence [2013] UKSC 41. However, the majority (para 76, per Lord Hope) were reluctant to impose positive obligations on the state in connection with the planning for and conduct of military operations in situations of armed conflict that are 'unrealistic or disproportionate'. In recognising a 'wide margin of appreciation' for states, the Court held that human rights obligations were less likely to be imposed where decisions were taken at 'a high level of command and closely linked to the exercise of political judgment and issues of policy.' This is to be decided on a case by case basis however.
} 
units to forego their right to protect themselves until the state is facing an undefined level of violence. How the gravity threshold is meant to operate in practice therefore is far from clear. We must assume that the ICJ did not intend for states to breach their international human rights obligations towards their own servicemen. Instead, it is perhaps safer to assume that they simply did not consider the micro level and how adhering to the gravity threshold as a matter of national policy has possible implications all the way down the chain of command. States should perhaps be cognisant of this fact if they are to ever consider limiting a serviceman's or unit's right to self-defence (e.g. by way of ROE) along the lines of the Nicaragua dictum. Not least to avoid any potential claims being brought by individuals (or their families) adversely affected by such policy. This relationship between human rights and the laws pertaining to the use of force is an evolving one however. Further analysis and development is required to appreciate fully the impact of human rights on the inherent right of self-defence. What the outcome would be in such circumstances is uncertain, but the fact that the issue might arise is both unfortunate and unnecessary.

\section{iv. Imminent armed attacks}

In the jus ad bellum, whether there exists a right of anticipatory self-defence in relation to armed attacks that are imminent is a controversial issue. It is not necessary for the purposes of this paper to enter into this debate but, even if the right is accepted, the debate does not stop there. ${ }^{95}$ The term 'imminence' occupies a grey area of law and its precise meaning is challenged. It is often said however to be reflected in the assertion that the necessity of selfdefence must be 'instant, overwhelming, and leaving (...) no moment for deliberation. ${ }^{96}$ For present purposes, it is sufficient to highlight a potential disconnect between an understanding of imminence as it pertains to national self-defence and imminence as it applies to personal and unit self-defence. Assuming a right of national self-defence in response to an armed attack that is imminent, then this understanding of imminence is a good starting point for the customary requirements of the jus ad bellum. At the micro level, as noted, individual servicemen and military units also have an inherent right to protect themselves from attacks that are imminent. Whether this understanding of imminence is the same as at the national level is a vitally important question. As with the Nicaragua gravity threshold, it relates to when the right of national self-defence is triggered. For units and individual servicemen, it has been suggested that 'most nations use a version of imminence defined in the Caroline Incident as, "instant, overwhelming, and leaving no choice of means, and no moment for deliberation." "97 For example, this definition forms the basis of NATO's self-defence policy,

\footnotetext{
${ }^{95}$ For a useful and recent overview of the relevant issues, see e.g James Green, 'The ratione temporis elements of self-defence' (2015) 2(1) Journal on the Use of Force and International Law 97.

${ }^{96}$ Letter from Mr Webster to Lord Ashburton (6 August 1842), British and Foreign State Papers, 1841-1842, Vol. XXX, 201. See section III.v below for further discussion of this point and the Caroline incident more generally.

${ }^{97}$ Randall Bagwell and Molly Kovite, 'It Is Not Self-Defense: Direct Participation In Hostilities Authority At The Tactical Level' (2016) 224 Military Law Review 1. For unit self-defence, Gill and Fleck, n 7, 484, agree that ' $\mathrm{t}$ ] he criteria applicable to the actual exercise of unit self-defence are the Caroline criteria: the use of force in
} 
which states that 'imminent means that the need to defend is manifest, instant, and overwhelming. ${ }^{98}$ If this is the case, then it would seem that both national and personal/unit self defence are approximately in alignment on this point and the trigger for the right (however that is determined) is part of a cohesive view of the application of defensive force.

However, a possible disconnect arises where imminence has a different meaning at the macro and micro levels. States have varying interpretations over the meaning of self-defence and when a defensive response is permitted under personal or unit self-defence. Consequently, the timing and manner of an authorized personal or unit defensive response may differ between states. ${ }^{99}$ For example, the United States asserts a right of national selfdefence in response to armed attacks that are imminent. ${ }^{100}$ Its national policy also recognizes a right of individual and unit self-defence in respect of attacks that are imminent. ${ }^{101}$ In the latter case however, it provides no clear definition of this term, other than stating that '[i]mminent does not necessarily mean immediate or instantaneous. ${ }^{102}$ At the micro level therefore, the United States adopts a conception of imminence that is a potentially broader than both the one that applies (under the jus ad bellum) at the national level and the one that other states might adopt to apply to their military. At the micro level, this blurs the line between offensive and defensive force, 'resulting in confusion on the requirements of selfdefense and causing U.S. policy to diverge from those of its coalition partners. ${ }^{\text {' }} 103$ This may have practical and dangerous consequences on the ground. For example, in a conflict involving a coalition, where United States forces call for fire support from other NATO forces and cite self-defence as the justification, the response may be delayed while the supporting command makes an independent determination of whether the threat is truly imminent based on their own national self-defence standard. This delay exposes soldiers on the ground to increased danger, makes United States commanders wary of relying on coalition partners, and ultimately weakens these alliances. ${ }^{104}$

Furthermore, it means at the macro level that the national self-defence of the United States might be triggered at an earlier stage than other states. This is because their servicemen can defend themselves under less clearly defined circumstances, outside of a situation that is 'instant, overwhelming, and leaving no choice of means, and no moment for deliberation.' This may extend to perceived security threats that are temporally more remote, risking a

self-defence must be immediately and unequivocally necessary; there must be no feasible alternatives to the use of force; and the force used must be proportional to the level of the attack being defended against.'

${ }^{98}$ Ibid, citing from NATO, MC 362/1, NATO Rules of Engagement.

${ }^{99}$ Gill and Fleck (n 7) 233.

${ }^{100}$ US Law of War Manual, 46-7.

101 The US SROE 2005 confirms a right of self-defence 'in response to a hostile act or demonstrated hostile intent'. It defines 'hostile act' to mean '[a]n attack or other use of force against the United States, US forces or other designated persons or property'. 'Hostile intent' is defined as '[t]he threat of imminent use of force against the United States, US forces or other designated persons or property'. Both definitions also include 'the threat of force to preclude or impede the mission and/or duties of US forces, including the recovery of US personnel or vital [US Government] property'. US SROE 2005, para 6(b)(1), Enclosure A, paras 3(e) and (f) respectively.

102 US SROE 2005, Enclosure A, paras 3(g).

${ }^{103}$ Bagwell and Kovite (n 97) 14.

${ }^{104} \mathrm{Ibid}$, 15-6. Bagwell, at footnote 82, notes his Afghanistan experience, observing that this situation was so pervasive in Afghanistan that the unified NATO command issued specific ROE in an effort to align United States forces and coalition partners on this critical issue. 
characterisation of preventative self-defence that is almost universally regarded as unlawful. ${ }^{105}$ On the rules of attribution discussed above, individual military personnel or units reacting in self-defence may therefore cause the United States to be in a de facto state of selfdefence. Whether or not this is pursued further at the state level, so that the defensive apparatus of the state as a whole is also mobilised as a result of a localised instance of selfdefence, will depend on whether the United States so chooses. However, if we accept that self-defence is unitary and that all acts of self-defence by military personnel thereby equate to acts of national self-defence, then the potential for an early exercise of the right potentially breaches the jus ad bellum rules of self-defence. This engages the international responsibility of the United States under the laws of state responsibility. However likely or otherwise this scenario, it does demonstrate a potential disconnect between the jus ad bellum rules (however unclear they may be) and the rules that apply to military personnel and units of certain states. Such a disconnect is undesirable and requires cohesive thinking to ensure that the rules at the top work in the same way as the rules at the bottom.

\section{v. Necessity and proportionality in the jus ad bellum}

Necessity and proportionality together govern the exercise of the right of self-defence and are requirements that apply to every form of self-defence discussed in this paper. ${ }^{106}$ For personal and unit self-defence, as noted, there are variations in the relevant domestic law, including the requirements of necessity and proportionality. In addition, the application of such rules does not always translate well into the military context. ${ }^{107}$ This section does not propose to offer an exhaustive review of these issues. Instead, it seeks to highlight certain key problems that disconnects in the law pose from the perspective of the jus ad bellum. These complexities have attracted little attention to date. For the purposes of the jus ad bellum and national selfdefence, the ICJ has consistently held that, under customary international law, a state's defensive response to an armed attack must be both necessary and proportionate. ${ }^{108}$ These central elements to the right of self-defence remain controversial and require further

\footnotetext{
105 Preventative self-defence is best represented by the so called 'Bush Doctrine' that advocated for a right of self defence in respect of (non-imminent) potential, unspecified future attacks. The National Security Strategy of the United States of America, September 2002, available at <http://www.state.gov/documents/organization/63562.pdf > The doctrine has been broadly condemned and is generally unsupported by states and academics alike. See e.g. Tom Ruys, 'Armed Attack' and Article 51 of the UN Charter: Evolutions in Customary Law and Practice (Cambridge University Press 2010) 322-4; Green (n 95) 106-7.

106 Gill and Fleck (n 7) 490.

${ }^{107}$ See ibid, 490-9, for an overview of these complexities.

108 Nicaragua, para 176; Nuclear Weapons, para 41; Oil Platforms, paras 73-7. In the post-UN Charter era, a contemporary understanding of these requirements is typically derived from the Caroline incident of 1837. More specifically, whilst disputed, it is common to state their provenance as the correspondence that arose out of it between Mr Webster, the American Secretary of State and Lord Ashburton, the British representative in Washington. The correspondence regarding the destruction of the steamboat Caroline can be found in British and Foreign State Papers, 1841-1842, Vol. XXX, 193. For a full commentary on, and analysis of, the incident, see Robert Jennings, 'The Caroline and McLeod Cases' (1938) 32(1) American Journal of International Law 82.
} 
clarification however. For now, a few observations may be made relating to the present examination that are pertinent to the meaning of these two requirements in the jus ad bellum.

\section{a) Necessity}

Following an armed attack, necessity acts as an immediate limitation on the availability of a state's right of self-defence. The use of defensive force is viewed as a measure of last resort, where there is 'no choice of means' ${ }^{109}$ The modern understanding of this requirement is that there must not be any non-military alternative to using it. ${ }^{110}$ In Ago's words:

[t]he reason for stressing that action taken in self-defence must be necessary is that the State attacked (or threatened with imminent attack, if one admits preventive selfdefence) must not, in the particular circumstances, have had any means of halting the attack other than recourse to armed force. In other words, had it been able to achieve the same result by measures not involving the use of armed force, it would have no justification for adopting conduct which contravened the general prohibition against the use of armed force. ${ }^{111}$

The disconnect in the relationship between national self-defence on the one hand and personal and unit self-defence on the other impacts on this requirement. In particular, it affects when the right of self-defence is exercisable. The temporal element of necessity, i.e. at what point in time necessity is satisfied, is intrinsically linked to the question of whether it is reasonable for a defending state to attempt to pursue alternative options not involving the use of force. Timing appears determinative to Webster's assertion that a state must in fact have 'no choice of means'. The question of necessity and the temporal elements of the right of self-

\footnotetext{
${ }^{109}$ Regarding the necessity of a state's ability to act in self-defence, Webster asserted that this was limited to cases in which the 'necessity of that self-defense is instant, overwhelming, and leaving no choice of means and no moment for deliberation.' Letter from Mr Webster to Lord Ashburton (6 August 1842), British and Foreign State Papers, 1841-1842, Vol. XXX, 201.

${ }^{110}$ Oscar Schachter,'The Right of States to Use Armed Force' (1984) 82 Michigan Law Review 1620, 1635-7; Elizabeth Wilmshurst, 'The Chatham House Principles of International Law on the Use of Force in SelfDefence' (October 2005), available at 〈http://www.chathamhouse.org/publications/papers/view/108106> (The Chatham House Principles) 7; Christine Gray, International Law and the Use of Force (Oxford University Press, 3rd edn 2008) 150; Dinstein (n 34) 232. See also Nicaragua, Judge Schwebel, diss op, 201 and 204. Note also that Art 51 UN Charter permits the exercise of national self-defence 'until the Security Council has taken measures necessary to maintain international peace and security.' Once the UNSC has adopted such 'necessary measures', the necessity of exercising self-defence ceases.

${ }^{111}$ Roberto Ago, 'Addendum to the Eighth Report on State Responsibility', (1980) UN Doc. A/CN.4/318/Add.57 , para 120 (emphasis added). It is generally agreed that states are only required to pursue other practical nonmilitary options that are available and that are likely to be effective. The Chatham House Principles, 7; Christopher Greenwood, 'International Law and the United States' Air Operation Against Libya' (1986-1987) 89 West Virginia Law Review 933, 945; Noam Lubell, Extraterritorial Use of Force Against Non-State Actors (Oxford University Press 2010) 45; Christian Tams and James Devaney, 'Applying Necessity and Proportionality to Anti-Terrorist Self-Defence' (2012) 45(1) Israel Law Review 91, 96; Daniel Bethlehem 'SelfDefense Against an Imminent or Actual Armed Attack by Nonstate Actors' (2012) 106 American Journal of International Law 770, 775.
} 
defence (including the notion of 'imminence' as noted above) is a hotly debated topic. For present purposes, this paper adopts the approach of the authors of The Chatham House Principles that: '[n]ecessity is a threshold and the criterion of imminence can be seen to be an aspect of it, inasmuch as it requires that there be no time to pursue non-forcible measures with a reasonable chance of averting or stopping the attack. ${ }^{112}$ As such, whether or not a state has an option to adopt non-forcible alternatives to self-defence will depend on whether an armed attack is on-going, imminent or completed. Given the above discussion regarding gravity and attribution, it is submitted that whether or not it is reasonable in the available time for a state to pursue non-military alternatives to force depends on the lowest common denominator of necessity. By this, it is meant that defensive force becomes necessary when, either at the state level or at the personal/unit level, force is the only way that an armed attack may be halted, repelled or prevented (if, in the latter case, one accepts a limited right of anticipatory self-defence against imminent armed attacks). ${ }^{113}$ It is imperative to make this point given that comments regarding the necessity of self-defence are often made solely from the perspective of the state and national self-defence. What is happening at the personal or unit level tends to be ignored.

To appreciate the significance of this point, let us take the situation of an on-going armed attack. Schachter contends that, where a state (which includes instrumentalities of a state such as warships, planes and embassies) is under current armed attack, then the necessity of defensive force is established per se, irrespective of probabilities as to the effectiveness of peaceful settlement. ${ }^{114}$ In such a scenario, there exists a present and exigent need for a state to protect itself by using force, without time to consider other options. Akande and Liefländer likewise argue that where self-defence is used in immediate response to an on-going attack by another state, ${ }^{115}$ practice indicates that a state is not required to seek or use alternative measures and, in such circumstances, there seems to be an 'almost irrebuttable presumption' that defensive force would pass the test of necessity. ${ }^{116}$ Green adopts a slightly more cautious position however. His contention is that, rather than necessity being established per se, where there is a large-scale attack on or invasion of a state's territory there exists a 'strong presumption' of necessity in favour of a forcible response. ${ }^{117}$

This debate is interesting on a number of levels. It is not clear from these commentators (other than Schachter) why necessity is only established where the degree of force used is

\footnotetext{
112 The Chatham House Principles, 7.

${ }^{113}$ As Ago affirms, speaking of self-defence in general terms, 'the objective to be achieved by the conduct in question, its raison d'être, is necessarily that of repelling an attack and preventing it from succeeding, and nothing else.' Ago (n 111) para 119. For those commentators and states that deny any right of anticipatory selfdefence, necessity and proportionality are reduced to become much narrower concepts. This is because the purpose of self-defence is narrowed to halting and repelling (not preventing) an armed attack.

${ }^{114}$ Schachter (n 110) 1635-6. Lubell (n 111) 43, 45, agrees, concluding that 'as long as the aggressor signals the intention to continue attacking, the necessity requirement may find itself swept aside fairly swiftly'.

${ }^{115}$ For the position regarding NSAs, see section III.vi.

${ }^{116}$ Dapo Akande and Thomas Liefländer, 'Clarifying Necessity, Imminence, and Proportionality in the Law of Self-Defence' (2013) 107 American Journal of International Law 563, 564.

${ }^{117}$ James Green, 'Docking the Caroline: Understanding the Relevance of the Formula in Contemporary Customary International Law Concerning Self-Defense' (2006) 14(2) Cardozo Journal of International and Comparative Law 429, 455.
} 
particularly high in such cases and not prima facie established in response to any form or degree of on-going armed attack. This is perhaps in response to (or a conflation of) the ICJ's statement in Nicaragua regarding the gravity threshold. This is not clear from their analysis however. Also insightful is the focus on the state perspective. Akande and Liefländer talk of an on-going attack by another state and Green of a large-scale attack on or invasion of a state's territory. Armed attacks by NSAs will be discussed below in section III.vi, but from both the perspective of attack and object of attack, the analysis is confined to the state level. In contrast to Schachter's position, it is by no means evident why Green confines his conclusion to uses of force against the territory of a state, rather than also to emanations of it.

If we look at the situation from the perspective of the individual serviceman or military unit, the conclusions are somewhat different. The scale of the attack (i.e. a full invasion or a minor use of force) makes no difference to the serviceman or the unit's right of self-defence. Depending if the applicable domestic law recognises the right to defend property, the object of the attack (be it territory or otherwise) may likewise be irrelevant. As a matter of law therefore, if the individual or unit is facing an unlawful use of force, then the necessity of a defensive response arises. At the jus ad bellum level, to avoid any disconnect with this position, Schachter's characterisation (where the necessity of defensive force is established per se where a state is under current armed attack) has to be preferred. If international law were to require that a state pursues and exhausts all available peaceful means to end or avert an on-going armed attack, this would require military personnel, who come under attack, to give up their lives without defending themselves. There would therefore be an obligation of self-sacrifice or suicide on the part of individuals on the ground to allow the state time to settle matters amicably at the international level. This would directly contradict the inherent right of personal and unit self-defence and would result in the reductio ad absurdum of the jus ad bellum. It has been noted judicially that 'the general principles of law recognized in all legal systems, contains a principle to the effect that no legal system is entitled to demand the self-abandonment, the suicide, of one of its subjects.' ${ }^{118}$ Furthermore, to require peaceful settlement in such circumstances, in lieu of forcible defence, potentially breaches the human rights obligations that states owe to their military. ${ }^{119}$ As Schachter rightly notes: '[o]ne could not say that a warship or a frontier guard is prohibited to repel an attack on the ground that there is no necessity for such defense because diplomatic steps might be taken to undo the wrong. ${ }^{120}$

\footnotetext{
${ }^{118}$ Nuclear Weapons, sep op, Judge Fleischhauer, para 5. See also diss op, Judge Shahabuddeen, para 155.

${ }^{119}$ See n 73 and accompanying text. As noted, this does not mean that no restrictions may be placed on the exercise of personal or unit self-defence, e.g. by ROE. A distinction should perhaps be made between an absolute requirement, as described in this example, and other potential limitations. For example, 'the tenets of military discipline and the interests of mission accomplishment may require that members of a military unit abstain from exercising their (assumed) right of personal self-defence under certain circumstances. Failure to do so or the absence of such restrictions would otherwise result in, for example, every member of a unit on patrol or on a covert mission having a personal right to open fire of his own volition on the basis of a personal threat perception, regardless or in contravention of the orders or intent of the unit commander.' Gill and Fleck (n 7) 495-6. Where the exact boundaries lie however between acceptable and unacceptable restrictions placed on the exercise of the right depends on a full understanding of both the jus ad bellum and international human rights law and the interaction between them. This is an area that would benefit from further exploration.

${ }^{120}$ Schachter (n 110) 1636.
} 


\section{b) Proportionality}

Supposing the necessity of the moment requires defensive action, Webster asserted that it would also be incumbent on a government purportedly acting in self-defence to show that it 'did nothing unreasonable or excessive; since the act, justified by the necessity of selfdefence, must be limited by that necessity, and kept clearly within it. ${ }^{121}$ This part of the Webster formula is the genesis of the modern requirement that, following an armed attack, where the exercise of the right of self-defence is established as necessary, that such exercise must then also be proportionate. As with the requirement of necessity, much controversy surrounds the meaning of proportionality in the jus ad bellum. Whilst alternative interpretations may be adopted, arguably the better view is that proportionality requires that the defensive responsive is not excessive (to use Webster's words) in relation to halting, repelling or preventing an armed attack. ${ }^{122}$ Regardless, these controversies should not prevent investigation as to the connection between proportionality as it relates to national self-defence and proportionality as it relates to personal and unit self-defence.

A proportionality analysis raises disparate issues at the different levels of self-defence. The first is a practical one; defending a state is not the same as defending the life of an individual or a unit (or property, if applicable in the relevant municipal law). Diverse strategic, policy and technical considerations apply. A proportionate response to minor force across a border is very different to considerations of deploying the military apparatus of an entire state against another state. What is proportionate in each case will be entirely fact dependent. At the conceptual level, the legal analysis is perhaps more interesting. In terms of personal self-defence, issues of the proportionality will be governed by either applicable domestic law or, in the case of international crimes, international criminal law. For unit selfdefence, there is some debate as to whether the proportionality rules that apply are governed by applicable domestic law or customary international law (including the jus ad bellum rules of necessity and proportionality). If domestic laws apply, these will vary from state to state. As such, one might conclude that there is a potential prima facie disconnect between personal and unit self-defence on the one hand and national self-defence on other. If unit self-defence is indeed governed by customary international law along the same lines of national selfdefence, this disconnect is markedly reduced. Further consideration and clarification of this issue is required.

However, when considering this question, it should be assumed that the macro and micro requirements of proportionality are coextensive. In this regard, an analogy can be drawn with the interaction between the jus ad bellum and the jus in bello. Whilst generally seen as

\footnotetext{
${ }^{121}$ Letter from Mr Webster to Mr Fox (24 April 1841), British and Foreign State Papers, 1840-1841, Vol. XXIX, 1138.

${ }^{122}$ Ago (n 111) para 121; Higgins (n 76) 232; Michael Schmitt (ed), Tallinn Manual on the International Law Applicable to Cyber Warfare (Cambridge University Press 2013) 62; Green (n 95) 101. It must be noted that not all commentators cited here accept a right of anticipatory self-defence and, as such, do not prescribe to the notion that a future armed attack may be 'prevented'. However, all the commentators referred to here agree with the notion that self-defence is limited to what is proportionate to the defensive necessity created by the armed attack and not some notion of an equivalence of scale or means. See further David Kretzmer, 'The Inherent Right to Self-Defence and Proportionality in Jus Ad Bellum' (2013) 24(1) European Journal of International Law 235.
} 
separate distinct regimes of international law, there are interactions and overlaps. On targeting for example, the two regimes have been described as broadly equivalent ${ }^{123}$ and the ICJ has also confirmed that the rules of proportionality in both regimes must be complied with for any use of force in self-defence to be lawful. ${ }^{124}$ The requirements are therefore cumulative. ${ }^{125}$ Likewise, proportionality in national self-defence, unit self-defence and personal self-defence should be viewed as joint requirements. They operate separately, but also coextensively to restrain and contain the scope of a defensive act so as to keep it truly defensive and to guard against excess. From the perspective of the jus ad bellum, because all self-defence involving military personnel is national self-defence, in order to be lawful, no act of self-defence can go beyond the customary requirements of necessity and proportionality. This is the case whether self-defence is an 'on-the-spot' reaction involving minimal localised force or a wider defensive response encompassing the military of the 'state as a whole'. Any additional requirements imposed by domestic laws or by ROE only serve to further limit the right at the unit and/or personal level. So, whilst the precise boundaries of proportionality at each level may be unclear, it is the jus ad bellum that is the ultimate restraining force. For those therefore who are uncomfortable with the suggestion that an act of self-defence at the micro level triggers self-defence of the state as a whole, it is the cumulative requirements of proportionality that speak to this concern. Whether the defensive response is at the national or at the personal/unit level (as a matter of factual description), the operation of international law means that the response can never be more than is necessary to achieve the aim of halting, repelling or (if anticipatory self-defence is accepted) preventing an armed attack.

\section{vi. Armed Attacks by Non-State Actors}

Undoubtedly, there is an increased threat to state security posed by NSAs that operate across and irrespective of state borders and beyond the control of states. The debates surrounding whether or not a right of national self-defence exists in response to armed attacks by NSAs are well known and it is not the purpose of this paper to rake over old ground. ${ }^{126}$ Whilst still a moot point, it is assumed for present purposes that (in line with the majority of academic opinion) there exists a right of national self-defence in response to armed attacks by NSAs, whether or not such attack is attributable to a state. For personal and unit self-defence, this is a non-issue. Attacks by NSAs, regardless of any state affiliation or connection, will constitute

\footnotetext{
${ }^{123}$ James Green and Christopher Waters, 'Military Targeting in the Context of Self-Defence Actions' 84 (2015) Nordic Journal of International Law 3, 13-25, which also includes discussion of the potential variances between the two regimes.

${ }^{124}$ Nuclear Weapons, 42.

125 Green and Waters (n 123) 13. See more generally Keiichiro Okimoto, 'The Cumulative Requirements of Jus ad Bellum and Jus in Bello in the Context of Self-Defense' (2012) 11 Chinese Journal of International Law 45.

${ }^{126}$ See e.g. Lubell (n 111); Christian Tams, 'The necessity and proportionality of anti-terrorism self-defence' in Larissa van den Herik and Nico Schrijver (eds), Counter-Terrorism Strategies in a Fragmented International Legal Order: Meeting the Challenges (Cambridge University Press 2013) 373-421; Kimberley. N. Trapp, 'Can Non-State Actors Mount an Armed Attack?' in Marc Weller (ed), Oxford Handbook on the Use of Force (Oxford University Press 2015) 679-696; Trapp (n 92); Olivier Corten, 'The 'Unwilling or Unable' Test: Has it Been, and Could it be, Accepted?' (2016) 29(3) Leiden Journal of International Law 777.
} 
an unlawful use of force, thereby triggering the right or personal and unit self-defence. This is regardless of the gravity of the attack. It is in the case of NSA attacks therefore that the Nicaragua gravity threshold issue (and the jus ad bellum more generally) is being tested the most. The result is an even greater risk of a disconnect between the two levels of self-defence.

One question that has arisen in respect of national self-defence is whether there should be a distinction between the gravity threshold as it applies to armed attacks by regular or irregular forces of a state on the one hand and NSAs not connected to a state on the other. The decision in Nicaragua did not touch upon this issue. The case was concerned with the attribution of NSA activity to a state, not NSAs acting independently. As such, the purview of the gravity threshold is limited to the inter-state context, i.e. where armed attacks are carried out by the regular forces of a state or NSAs, where the activities of the latter are attributable to the state. What then of non-attributable armed attacks by NSAs? Some have suggested that, for terrorist attacks by NSAs, the gravity threshold should be higher. Cassese has argued that:

[t]o qualify as an armed attack, international law requires that terrorist acts form part of a consistent pattern of violent terrorist action rather than just being isolated or sporadic attacks (...) it follows that sporadic or minor attacks do not warrant such a serious and conspicuous response as the use of force in self-defence.' ${ }^{127}$

His argument is based, inter alia, on the premise that '[s]tates can only have recourse to military force as a last resort, for the goal of international peace must always be the overriding factor in international relations. ${ }^{128}$ The suggestion that there is a higher level of violence is required before an attack by independent NSAs constitutes an 'armed attack' for the purpose of Article $51 \mathrm{UN}$ Charter has received support from other leading jus ad bellum scholars. ${ }^{129}$ The rationale for a higher threshold relates to the role of the state on whose territory such NSAs are operating (the host state). In this regard, the host state has the primary responsibility for the prevention and suppression of such acts and the higher threshold 'recognizes that such state (...) would be affected by the force used in self-defence and ensures that self-defence and the consequences for that state or states that flow from a military response are not triggered too soon. ${ }^{130}$ This may well be true and there is much to be said about the logic of this conclusion. Along similar lines, Akande and Liefländer have posited that a threat of attack by a 'series of suicide bombers' may 'just barely' be viewed as reaching the gravity threshold for an armed attack. ${ }^{131}$

There are a number of issues with this general approach to armed attacks by NSAs. The first is whether insisting on an increased threshold of violence, which relates to the armed

\footnotetext{
${ }^{127}$ Antonio Cassese, 'The International Community's 'Legal' Response to Terrorism', (1989) 38 International \& Comparative Law Quarterly 589, 596.

128 Ibid

${ }^{129}$ E.g. Lubell (n 111) 51; Chatham House Principles, 11-13. Corten (n 126) 794, makes the same argument for a higher threshold in the context of the 'unable or unwilling' debate, where a state is tolerating or acquiescing in the activities of the NSAs or assisting them.

${ }^{130}$ Nico Schrijver and Larissa van den Herik, 'Leiden Policy Recommendations on Counter-Terrorism and International Law' (2010) 57(3) Netherlands International Law Review 531

${ }^{131}$ Akande and Liefländer (n 116) 567.
} 
attack, addresses the aforementioned concern in the most effective manner. Arguably, the emphasis on action by the host state to deal with NSA armed attacks is an issue of necessity, not an issue of the level of violence perpetrated by those operating from the host state's territory. If effective action against the NSAs is taken by the host state, such that it halts the attacks and the continuing threat, this potentially renders the use of force in self-defence on the part of the victim state unnecessary. Host state action, to use Webster's words, thereby offers an additional 'choice of means' to that seen in the inter-state context. Further, for present purposes, the problem is that the call for a higher threshold follows analysis that takes place very much at the state level. It pertains to the right of national self-defence, with a focus on the sovereignty and territorial integrity of the states concerned. There seems to be little or no consideration given to the issue of personal and unit self-defence.

As a starting point, let us take Akande and Liefländer's suicide bomber example. The fact that a distinction is made here between armed attacks by NSAs and the forces of a state is troubling. The authors provide no further justification for this view. If the suicide bombers were dressed in regular army uniforms so as to resemble a 'conventional attack' by a state's regular armed forces, would such a distinction still hold? It seems doubtful. At the micro level, an attack is an attack, regardless of whether the aggressors are private citizens (i.e. NSAs not connected to any state) or public ones sent by or on behalf of a state. For the individual servicemen and military units on the ground it makes no difference if their attackers are wearing uniform or not, if they are connected in some way to a state or not, or whether they are undertaking a series of attacks or just one. For them, any distinction regarding the gravity of violence based on the identity of the attacker is meaningless. How are they even to assess this and why should they? The damage that the attackers may inflict on persons and property is the same and, in each case, provided the attack is unlawful, the right of personal and unit self-defence will arise. If the right does arise and it is necessary to exercise it, then the above analysis regarding the threshold and attribution applies so that the right of national self-defence also arises and is exercisable. What happens on the ground, at sea and in the air should therefore be taken into account when proposing any different levels of violence that may or may not be required to engage a right of self-defence. Such connected rationalisation recognizes the fact that force is directed at people and property and not just 'states' in any abstract sense.

As such, any threshold of gravity should apply equally to attacks by states and NSAs. ${ }^{132}$ Otherwise, a disconnect arises between the two levels of self-defence. What the response is to that armed attack is a related, but separate, issue. It may be that the response is at a localised or a state level. A response to an attack by a lone gunman or small group of terrorists might be one of criminal law enforcement action, whereas a large scale attack (for example on the scale of 9/11) might require a larger defensive response by the state 'as a whole'. These are all questions to be judged against the requirements necessity and proportionality however, not the gravity of the attack or the identity of the attacker. In addition, to who/what that defensive force is directed, e.g the NSAs alone, the state that is harbouring or supporting them, or both, is also best analysed by reference to necessity and proportionality. Making a distinction

\footnotetext{
${ }^{132}$ Steven Ratner, 'Self-defence against terrorists: the meaning of armed attack' in Herik and Schrijver (n 126) 341 , reaches the same conclusion.
} 
between attacks by states and NSAs confuses the threshold question with issues of attribution (to a state) and the target of defensive force (being either the state, the NSAs only, or both). It also conflates the issue with considerations of necessity and proportionality, which are fundamentally separate issues. Ensuring that the right of personal and unit self-defence form part of the analysis helps to clarify this confusion.

\section{Conclusion}

This paper has highlighted some of the issues associated with the focus to date on national self-defence. It seeks to offer a cohesive deliberation that involves analysis of the jus ad bellum that encompasses considerations of personal and unit self-defence. It does not seek to provide comprehensive answers to all of the issues raised by the disconnect between national self-defence and unit and personal self-defence. Instead, it recognizes that this often neglected area of the jus ad bellum is central to some of the key debates pertaining to the right of selfdefence. The aim is to invite debate on the issues raised and further scholastic and judicial consideration in order to bridge the present disconnect.

That there is a disconnect between the levels of self-defence is clear. Whilst states, often through their ROE, recognise the inherent right for their military personnel and units to defend themselves in the face of actual or imminent aggression, such recognition often does not translate into, or marry with, the rules that apply to the right of national self-defence. This is despite the fact that the jus ad bellum treats self-defence in a unitary manner. To ensure that there is no disconnect between the law as it applies to national self-defence and the law as it applies to unit and personal self-defence, it must be appreciated that any exercise of the latter also constitutes an exercise of the former. We must therefore consider the range of consequences of saying that a state has no right of self-defence against minor uses of force, or attacks by NSAs, or armed attacks that are imminent. The effect may be on the individual rights of servicemen and military units, both in terms of their right to defend themselves and also their human right to be protected by their own state. It may also impact on the responsibility of the relevant state, which may be triggered by the acts of it military forces and also how it does or does not comply with it human rights obligations. This in turn may also have a wider effect on the cohesiveness of international law, where the rules of the jus ad bellum operate so as to cause friction with the other normative regimes. This unnecessary fragmentation of international law is a result of the lack of cognizance of the whole picture. By focusing on national self-defence, we are forgetting the individual. At the heart of all conflicts are human beings. Both international human rights law and IHL operate to reduce the atrocities of war and safeguard human life. The jus ad bellum should be understood to operate in a way that takes the same approach. It should recognize that individuals and groups of individuals have a right to protect themselves and that the state has an obligation to protect them. Furthermore, an understanding of the jus ad bellum should admit that it is meaningless to say that a state does not have a right of self-defence in circumstances where individuals and units do.

The jus ad bellum rules should be the same and apply at each level in a coherent manner. Theory must marry with, and be informed by, operational practice. If an individual 
serviceman can respond to protect his life against even the most minor exercise of force, then this should be reflected in the jus ad bellum rules and in the contemplation of those who apply and interpret it. The present disconnect can only be bridged with scholarship and jurisprudence that takes a holistic approach. It must look at self-defence in a unified fashion that considers how the different levels of self-defence work together and affect each other. Many of the controversies within the jus ad bellum would benefit from this missing piece of the puzzle. 